\title{
Effect of 3-month treatment of children and adolescents with familial and polygenic hypercholesterolaemia with a soya-substituted diet
}

\author{
Daniel Weghuber ${ }^{1,2}$ and Kurt Widhalm ${ }^{1 *}$ \\ ${ }^{1}$ Division of Clinical Nutrition and Metabolism, Department of Paediatrics, Vienna Medical School, Vienna, Austria \\ ${ }^{2}$ Department of Paediatrics, Paracelsus Private Medical School, Salzburg, Austria
}

(Received 12 January 2007 - Revised 28 June 2007 - Accepted 29 June 2007)

Soya protein has well-documented beneficial effects on serum lipid levels in adults, the potential beneficial effect of a prolonged soya proteinsubstituted diet in children and adolescents with familial $(\mathrm{FH})$ and polygenic hypercholesterolaemia $(\mathrm{PH})$ being unknown. To assess the effect of 3 months' treatment of children and adolescents with FH and PH with a soya-substituted diet on serum lipids and lipoproteins, twenty-three children and adolescents were initially assigned to a standard phase 1 diet for 3 months, after which they were instructed to include soya protein $(0.25-0.5 \mathrm{~g} / \mathrm{kg}$ body weight) into their diet for 3 months. Sixteen patients (ten males and six females, thirteen with FH (eight males and five females), three with PH (two males and one female); mean age 8.8 (SD 4.2) years (range 4-18 years); mean BMI $\left.16.7(\mathrm{SD} 2.6) \mathrm{kg} / \mathrm{m}^{2}\right)$ ) completed both phases. The phase 1 diet resulted in a significant reduction of total cholesterol (TC), LDL-cholesterol and apo B by $12.3,11.8$ and $10.6 \%$, respectively, HDL-cholesterol, TAG, apo A1 and lipoprotein(a) not being different. Dietary intake of soya protein during phase 2 resulted in a significant decrease of TC, LDL-cholesterol and apo B by 7.7, 6.4, and 12.6\%, respectively. TAG, HDL-cholesterol, apo A1, and lipoprotein(a) did not change significantly. Substitution of soya protein for animal protein in a low-fat, fat-modified diet is of additional benefit in many, but not all, children and adolescents with FH and PH when aiming at lowering serum TC, LDL and apo B. It seems to be a feasible long-term dietary lifestyle intervention and may grant additive benefit in the prevention of early vascular disease.

Children: Adolescents: Hypercholesterolaemia: Soya-substituted diets: Prolonged treatment

More than three decades ago, the American Academy of Pediatrics recommended starting the primary prevention of atherosclerosis as early as 2 years of age ${ }^{1}$. Since then, autopsy studies have demonstrated that early coronary atherosclerosis or precursors originate in childhood and adolescence, and are correlated with high serum total cholesterol (TC) and LDL-cholesterol (LDL-C) levels, and low HDL-cholesterol (HDL-C) levels. Monogenic factors that cause high cholesterol levels include familial hypercholesterolaemia (FH). Polygenic hypercholesterolaemia (PH) results from the expression of multiple genes combined with environmental effectors such as diet high in saturated fat and cholesterol levels as early as during childhood ${ }^{2}$. There are documented data that in adolescents with FH functional and morphological signs of premature atherosclerosis can already be endetected and it is assumed that these deleterious sequelae may be postponed by an early reduction in atherogenic lipoproteins ${ }^{3}$. Moreover, serum cholesterol levels above the 95 th percentile (i.e. $>1300 \mathrm{mg} / \mathrm{l}$ ) due to $\mathrm{PH}$ should also be encountered ${ }^{4}$. Thus, it is generally accepted within the paediatric field that children and adolescents affected by hypercholesterolaemia should be treated as soon as possible in order to reduce their elevated cholesterol levels. The cornerstone of all therapeutic regimens is the dietary approach. By means of a classical diet (low-fat, high-MUFA and -PUFA) a decrease of LDL-C in the range of $10-15 \%$ can be achieved $^{5-7}$. Moreover, soya protein has well-documented beneficial effects on serum lipid levels in adults, the changes being related to the level and duration of intake and initial serum lipid concentrations ${ }^{8}$. The American Heart Association Nutrition Committee has recently summarised available adult data, indicating that the beneficial LDL-C-lowering effect is within the range of a few percentage points ${ }^{9}$. Also, diets with substitution of animal protein by soya protein have an additional lowering effect in some but not in all patients ${ }^{10-12}$.

Acknowledging this body of information in the adult population, the lack of studies assessing the potential beneficial effect of soya protein in children and adolescents affected by FH appears surprising, especially in the face of the cited need for early preventive measures. This is particularly true when it comes to the evaluation of the effect and feasibility of such an intervention over a prolonged period of time, thus depicting a 'real-life scenario' $v$. a mere shortterm intervention. In this regard, acceptance of soya products is of great importance. Information on whether or not soya products are accepted by the patient is key to the concept of long-term therapy.

The present study aimed to examine whether a sustained cholesterol-lowering effect of a soya protein diet can be 
achieved in children and adolescents with proven $\mathrm{FH}$ and $\mathrm{PH}$ during a period of at least 3 months. In addition, acceptance and preference of soya products was assessed.

\section{Patients and methods}

Subjects

Initially, twenty-three patients (twelve males; eleven females), eight with $\mathrm{FH}$ (four males; four females), fifteen with $\mathrm{PH}$ (eight males; seven females) who presented sequentially to the Paediatric Out-patient Department of Clinical Nutrition and Metabolism at Vienna Medical University Hospital for treatment were included in the programme. Mean age was 8.8 (SD 4.2) years (range 4-18 years). All patients were otherwise healthy with BMI being 16.7 (SD 2.6) $\mathrm{kg} / \mathrm{m}^{2}$ at baseline (Table 1). FH was diagnosed either by LDL-receptor gene analysis or if the following criteria were fulfilled: LDL-C $>1550 \mathrm{mg} / \mathrm{l}$, TC $>2700 \mathrm{mg} / \mathrm{l}, \mathrm{TAG}<1000 \mathrm{mg} / \mathrm{l}$ and at least one family member diagnosed with $\mathrm{FH}^{13}$. Patients were considered to have PH if LDL-C exceeded $1300 \mathrm{mg} / 1$ without MEDPED criteria being fulfilled. Patients on treatment with lipid-lowering drugs or medication known to influence lipid metabolism were excluded. Finally, data of sixteen patients (ten male and six females; eight patients with $\mathrm{FH}$ (four male and four female) and eight patients with $\mathrm{PH}$ (six male and two female)) were available for evaluation. Thus, seven patients had to be excluded, two of them having been diagnosed with soya protein allergy, and five not adhering to either phase 1 or phase 2 diet as documented in repeated dietary records. Patients with $\mathrm{FH}$ and $\mathrm{PH}$ had significantly different baseline TC and LDL-C levels (351.4 (SD 91.9) $v$. 257.6 (SD 30.4) $\mathrm{mg} / \mathrm{l}$ and 253.4 (SD 56.4) v. 178.3 (SD 33.3) $\mathrm{mg} / \mathrm{l})$. The patients excluded did not differ from those included in regard to age, BMI and baseline serum levels of the measured lipoproteins. All procedures were performed according to the Helsinki Declaration of 1975 as revised in 1996 and according to guidelines of Good Clinical Practice.

\section{Methods}

All subjects underwent a thorough physical examination. Blood samples were taken for determination of fasting serum lipoproteins (TC, LDL-C, HDL-C and TAG) at baseline, after 3 months (end of phase 1) and after 6 months (end of phase 2) following an overnight fast. Cholesterol and TAG levels were measured enzymically by using test kits from Boehringer Mannheim GmbH (Mannheim, Germany): CHOD-PAP and GPO-PAP (enzymic colorimetric methods), respectively. VLDL were removed by ultracentrifugation ${ }^{14}$. Apo A1,

Table 1. Patient characteristics (n 16)

(Mean values and standard deviations)

\begin{tabular}{lccc}
\hline & Mean & & SD \\
\hline Males $(n)$ & \multicolumn{3}{c}{10} \\
Females $(n)$ & \multicolumn{3}{c}{6} \\
Age (years) & $8 \cdot 8$ & & 4.2 \\
Age range (years) & & $4-18$ & \\
Baseline BMI $\left(\mathrm{kg} / \mathrm{m}^{2}\right)$ & $16 \cdot 7$ & & 2.6 \\
\hline
\end{tabular}

B and lipoprotein(a) were measured by nephelometry with test kits from Boehringer Mannheim.

\section{Diet}

After inclusion into the programme patients were to follow a diet reduced in SFA, modified in fatty acid pattern (increase in MUFA and PUFA) and rich in complex carbohydrates and phytonutrients for 3 months (phase 1 diet). Thereafter, patients and their parents were instructed to include soya protein of at least $0.25 \mathrm{~g} / \mathrm{kg}$ body weight into their diet for a period of 3 further months, thereby substituting soya protein for animal protein (Fig. 1). This was achieved by the introduction of soya foods (Alpro soya dairy-free milk alternatives), which were consumed substituting dairy protein and/or a mixture of other animal proteins. Each patient was instructed to consume a minimum amount of soya products per d. Adherence to both types of diet was assessed by means of multiple 1-week dietary records, which a registered dietitian discussed with the patient and parents in detail whereby written material containing personalised dietary recommendations was provided. Patients and their families were seen weekly throughout the first month, thereafter after 2 and 3 months of each phase. If a patient did not show up to an appointment, an alternative appointment was sought by the dietitian, thereby maximising adherence. Quantitative fatty acid intake was calculated by analyses of the dietary records. The content of isoflavones in the soya products used was on average $27 \mathrm{mg}$ isoflavones per $10 \mathrm{~g}$ soya.

\section{Assessment of acceptance and preference of soya products}

A questionnaire was handed out to patients, all of which were returned. Patients had to judge the overall taste of the consumed products as 'very good', 'fair' and 'bad'. In addition, patients were asked to list their three favourite products, from which a ranking was made.

\section{Statistical analysis}

Comparisons between baseline and post-intervention data were tested by an unpaired $t$ test with a significance level of $5 \%$ and two-sided $95 \%$ confidence limits. Calculations were conducted using Statistical Analysis Software (version 8.2; SAS Institute Inc., Cary, NC, USA).

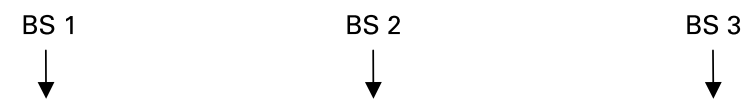

Soya protein $>0.25 \mathrm{~g} / \mathrm{kg} \mathrm{BW}$

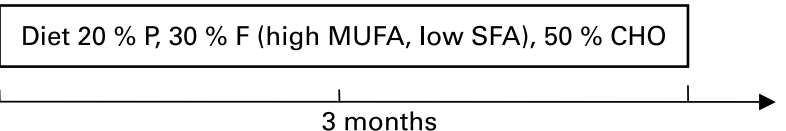

Fig. 1. Study protocol. BS, blood sample; BW, body weight; P, protein; F, fat; $\mathrm{CHO}$, carbohydrates. 


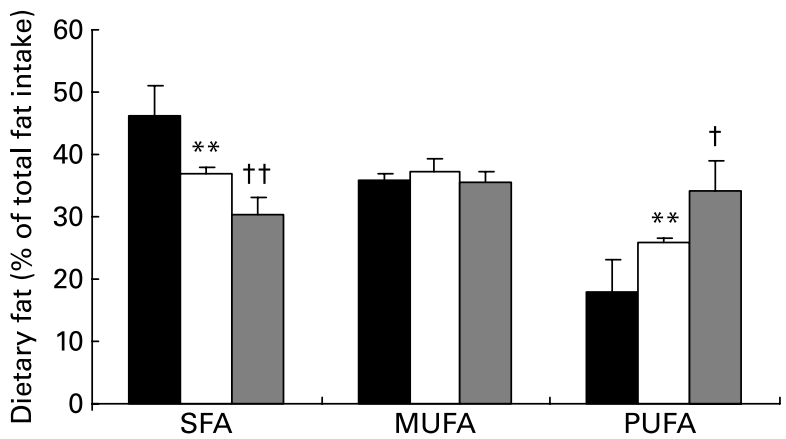

Fig. 2. Intake of dietary fat in percentage of total fat intake at baseline ( $\square$ ) after phase $1(\square)$ and after phase $2(\square)$. Values are means, with their standard deviations represented by vertical bars. ${ }^{*}$ Mean value is significantly different from that at baseline $(P<0.0001)$. Mean value is significantly different from that at the end of phase 1 : $† P<0.001$, †† $P<0.0001$.

\section{Results}

Patient characteristics are presented in Table 1. BMI did not change significantly during both phases (data not shown).

\section{Adherence to diet}

Fatty acid intake, presented as percentage of total dietary fat intake, is shown in Fig. 2. SFA intake decreased significantly by $20 \%$ from baseline to the end of phase 1 (46.1 (SD 5.1) $v$. 36.9 (SD 0.9) \%, respectively; $P<0.0001$ ) and by $18 \%$ from the end of phase 1 to the end of phase $2(36.9$ v. $30.3 \%$, respectively; $P<0 \cdot 0001)$. At the same time, intake of PUFA significantly increased by $44.1 \%$ during phase 1 (17.9 (SD 5.1) v. 25.8 (SD 0.9) \%, respectively; $P<0.0001$ ) and by $32.9 \%$ during phase $2(25.8$ (SD 0.9) v. 34.3 (SD 4.7) \%, respectively; $P<0.001)$. The SFA:PUFA ratio decreased from 2.6 to 1.4 to 0.9 , respectively $(P<0.0001)$. TC intake was 242 (SD 56) $\mathrm{mg}$ at baseline, being significantly lower after phase 1 (132 (SD 23) mg; $P<0.0001)$ and phase $2(110$ (SD 11) $\mathrm{mg} ; P<0.01$ ). Dietary intake of MUFA did not change significantly during the phases. Average soya protein intake during phase 2 was 0.50 (SD 0.20 ) g/ $/ \mathrm{kg}$ body weight, with no statistically significant difference between patients with $\mathrm{PH}$ and $\mathrm{FH}$.

\section{Serum cholesterol levels}

The phase 1 diet resulted in a significant reduction of serum concentrations of TC, LDL-C and apo B by $12 \cdot 3,11.8$ and
$10.6 \%$, respectively, serum concentrations of HDL-C, TAG, apo A1 and lipoprotein(a) not yielding statistical differences (Table 2).

Dietary intake of soya protein during phase 2 resulted in a significant decrease of serum concentrations of TC, LDL-C and apo B by $7 \cdot 7,6.4$ and $12.6 \%$, respectively. Serum concentrations of TAG, HDL-C, apo A1 and lipoprotein(a) did not change significantly (Table 3 ).

\section{'Non-responders' v. 'responders' to soya protein}

While twelve of the sixteen patients presented with lower TC levels, for four patients no decrease of TC was seen at the end of phase 2. The former subjects were considered to be 'responders', the latter 'non-responders'. There was no significant difference between the groups in regard to age, BMI, change in BMI, relative amount of SFA, MUFA and PUFA intake during the phases, and baseline serum levels of the measured lipoproteins (data not shown). Table 4 presents laboratory data of the groups. Serum levels of HDL-C and apo A1 of responders $v$. non-responders were comparable at the end of phase 1 , but significantly differed at the end of phase 2 (Table 4).

\section{Level of acceptance and preference}

Six patients qualified the consumed soya products as 'very good', nine as 'fair' and none as 'bad'. Alpro chocolate soya drink and dessert were ranked top before vanilla soya drink and dessert, plain yoghurt alternative and strawberry drink.

\section{Discussion}

To the best of our knowledge the present study is the first to show that prolonged substitution of soya protein for animal protein in a low-fat, fat-modified diet is of additional benefit when aiming to lower serum concentrations of $\mathrm{TC}$ and LDL-C in children and adolescents with FH and PH. Moreover, the present study underscores the importance of diet as the cornerstone of lipid-lowering therapy.

The effect of a diet low in SFA and high in unsaturated fatty acids (phase 1 diet) on reduction in TC and LDL-C achieved by our children is in accordance with other studies in children, adolescents and adults ${ }^{5,6}$. While a recent meta-analysis on the effect of soya protein on the lipid profile in adults identified thirteen studies with a duration of 12 and more weeks

Table 2. Serum lipid concentrations at baseline and after the phase 1 diet (Mean values and standard deviations for sixteen subjects)

\begin{tabular}{|c|c|c|c|c|c|c|}
\hline \multirow[b]{2}{*}{ Lipid (mg/l) } & \multicolumn{2}{|c|}{ Baseline phase 1} & \multicolumn{2}{|c|}{ End of phase 1} & \multirow[b]{2}{*}{ Change (\%) } & \multirow[b]{2}{*}{$P$} \\
\hline & Mean & SD & Mean & SD & & \\
\hline Total cholesterol & 304.5 & $82 \cdot 0$ & $267 \cdot 2$ & 53.9 & $-12 \cdot 3$ & $<0.002$ \\
\hline LDL-cholesterol & $215 \cdot 8$ & $59 \cdot 2$ & $190 \cdot 3$ & $56 \cdot 4$ & $-11 \cdot 8$ & $<0.0003$ \\
\hline HDL-cholesterol & $55 \cdot 6$ & $14 \cdot 7$ & $54 \cdot 0$ & $11 \cdot 7$ & -2.9 & NS \\
\hline TAG & $100 \cdot 7$ & $56 \cdot 0$ & $83 \cdot 2$ & 24.5 & $-17 \cdot 4$ & NS \\
\hline Lipoproteinp(a) & $44 \cdot 8$ & $43 \cdot 0$ & $26 \cdot 7$ & 21.9 & -37.4 & NS \\
\hline Apo $A 1$ & $147 \cdot 2$ & 37.8 & 143.8 & $22 \cdot 8$ & $-2 \cdot 3$ & NS \\
\hline Apo B & $134 \cdot 1$ & $36 \cdot 7$ & $119 \cdot 9$ & $24 \cdot 6$ & $-10 \cdot 6$ & $<0.05$ \\
\hline
\end{tabular}


Table 3. Serum lipid concentrations before and after the phase 2 (soya-substituted) diet (Mean values and standard deviations for sixteen subjects)

\begin{tabular}{|c|c|c|c|c|c|c|}
\hline \multirow[b]{2}{*}{ Lipid (mg/l) } & \multicolumn{2}{|c|}{ Baseline phase 2} & \multicolumn{2}{|c|}{ End of phase 2} & \multirow[b]{2}{*}{ Change (\%) } & \multirow[b]{2}{*}{$P$} \\
\hline & Mean & SD & Mean & SD & & \\
\hline Total cholesterol & $267 \cdot 2$ & 53.9 & $246 \cdot 7$ & $48 \cdot 0$ & -7.7 & 0.01 \\
\hline LDL-cholesterol & $190 \cdot 3$ & $56 \cdot 4$ & $178 \cdot 2$ & $53 \cdot 8$ & $-6 \cdot 4$ & $<0.02$ \\
\hline HDL-cholesterol & 54.0 & 11.7 & 53.2 & $15 \cdot 1$ & 1.5 & NS \\
\hline TAG & $83 \cdot 2$ & 24.5 & 86.5 & 34.4 & 4 & NS \\
\hline Lipoprotein(a) & $26 \cdot 7$ & $21 \cdot 9$ & $36 \cdot 2$ & $29 \cdot 8$ & 29 & NS \\
\hline Apo A1 & $143 \cdot 8$ & $22 \cdot 8$ & $160 \cdot 5$ & $29 \cdot 9$ & $11 \cdot 6$ & 0.06 \\
\hline Apo B & $119 \cdot 9$ & $24 \cdot 6$ & 104.8 & $27 \cdot 3$ & $-12 \cdot 6$ & $<0.04$ \\
\hline
\end{tabular}

(maximum 26 weeks) ${ }^{8}$, previous studies in children and adolescents have demonstrated a beneficial effect of a soyabean-substituted diet with hypercholesterolaemia only for short-term interventions ${ }^{12,15}$. The present study participants achieved a significant reduction of TC and LDL-C in an extended design of 3 months. The extent of the reduction in TC and LDL-C is comparable with those presented in the meta-analysis of Andersen et al. with baseline TC between 2600 and $3350 \mathrm{mg} / 1$ in adults ${ }^{16}$, yet more than reported by Sacks et $a l .{ }^{9}$. These authors stated in their American Heart Association Science advisory that a very large amount of soya protein, more than half the daily protein intake, may lower LDL-C by a few percentage points when it replaces dairy protein or a mixture of animal proteins ${ }^{9}$. Two previous studies investigating the effect of a soya protein-substituted diet in children in a shorter design found a significant larger reduction of TC and LDL-C $\mathrm{C}^{11,12}$. The difference may be explained by the greater hypocholesterolaemic effect of the run-in (phase 1) diet in the present study, and possibly by a negative dose-response relationship between length of intervention and the decline in LDL-C, as reported in adults by Zhan \& $\mathrm{Ho}^{8}$. However, it is necessary to acknowledge that not all of the patients achieved a reduction in TC and LDL$\mathrm{C}$ in the present study. Our data demonstrate that serum levels of TC and LDL-C were not decreased by the addition of soya protein in four of the sixteen patients, even though the 'non-responders' had lower levels of TC and LDL-C after introduction of the phase 1 diet. In comparison, Rose et al. reported a reduction in only half of the children with
$\mathrm{FH}^{17}$. Introduction of a soya protein-substituted diet did not result in a significant change in serum levels of HDL-C in the present study group. This is in accordance with some $e^{18-20}$ but in contrast to other adult studies showing moderate increases in HDL- $\mathrm{C}^{16}$. Yet, apo A1 levels were increased by trend, which is in agreement with studies demonstrating increased apo A1 secretion and gene expression in liver cells $^{21}$. On the other hand, it must be mentioned that while there was no significant difference regarding age, BMI, change in BMI, relative amount of SFA, MUFA and PUFA intake during the phases, and baseline serum levels of the measured lipoproteins, the group of 'non-responders' tended to have higher levels of HDL-C and apo A1 at the end of phase 1. Moreover, patients regarded as 'non-responders' had significantly higher concentrations of serum HDL-C and apo A1 than their TC- and LDL-C-responsive counterparts after inclusion of soya protein into their diet. Thus, 'responders' and 'non-responders' yielded beneficial effects of soya protein substitution, although on different serum lipoproteins. This variable lipaemic response has also been shown to be existent in healthy, normolipaemic men ${ }^{22}$. We can only speculate on the reason of this variable response, differing genetic background, i.e. underlying mutations of the LDL-receptor, being a possible cause. However, interpretation of these data demands precaution since serum lipoprotein levels can change substantially from day to day. Also, the small number of patients in the 'non-responder' group needs to be taken into consideration. Therefore, further studies specifically looking at the responder $v$. non-responder issue are warranted.

Table 4. Serum lipid concentrations at baseline, at the end of the phase 1 diet and at the end of the phase 2 diet for 'responders' (R; $n$ 12) and 'non-responders' (NR; n 4) to soya protein

(Mean values and standard deviations)

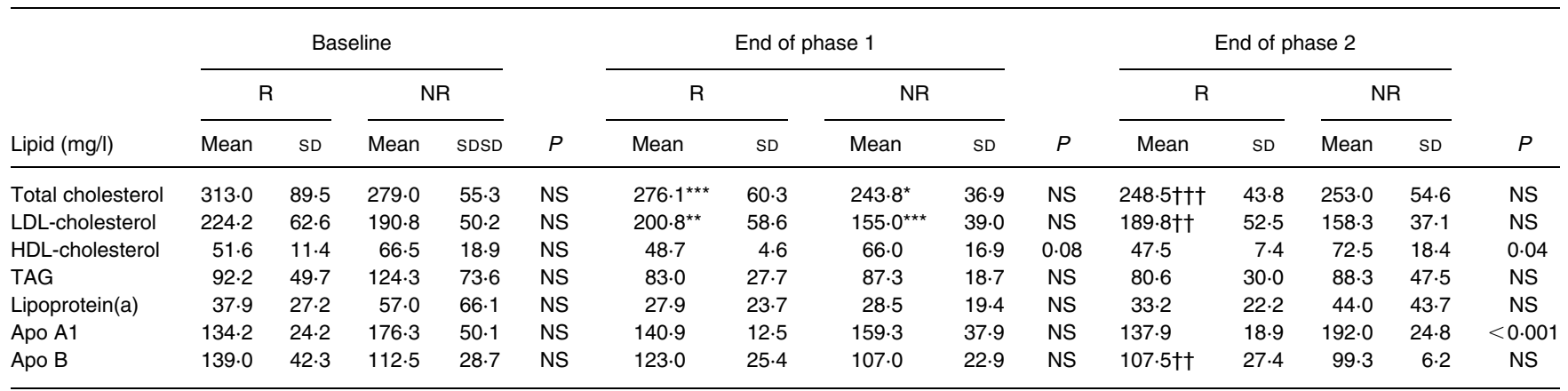

Mean value is significantly different from that of the same group at baseline: ${ }^{\star} P<0.05,{ }^{\star *} P=0.02,{ }^{\star \star *} P=0.01$.

Mean value is significantly different from that of the same group at the end of phase 1 : $† \dagger P=0.02, \dagger \dagger \dagger P<0.01$. 
As far as the mechanisms underlying the cholesterol-lowering effect of soya protein are concerned, multiple explanations have been presented. There is evidence that soya protein enhances LDL-receptor activity in $\mathrm{FH}^{23}$. In this regard, LDL-receptor expression in the liver has been shown to be stimulated by the $7 \mathrm{~S}$-globulin of soya protein ${ }^{24}$. This isolated protein component and its active subfractions might stimulate LDL-receptors by direct interaction with gene promoters ${ }^{25}$. Other studies suggest an association with factors involved in the digestion of the proteins, absorption of their constituent amino acids, and with mechanisms of both catabolism and excretion of cholesterol ${ }^{26,27}$. The approximate $13 \%$ decrease in apo B paralleling levels of TC and LDL-C in our patients is in accordance with data showing that the soya phyto-oestrogens genistein and daidzein decrease apo B secretion from HepG2 cells through multiple mechanisms by lowering cholesterol synthesis, cholesterol esterification, microsomal TAG transfer protein, and enhancing LDL-receptor activity ${ }^{28}$. Moreover, soya protein has been suggested to act as a strong antioxidant ${ }^{29}$.

It needs to be taken into consideration that even though we had a 3-month run-in phase, we could not test the effect of a soya-substituted diet against a control group. This was due to the fact that almost all parents of the children eligible for the study insisted on their child receiving any possible nutritional therapy, thus being in the intervention group.

In addition, it is of note that the present study allows us to positively answer the question whether it is feasible to introduce soya products into the diet of children and adolescents over a period of at least 3 months. Evaluation of dietary protocols and specifically designed questionnaires revealed high levels of acceptance, which is a precondition for this type of dietary therapy. Importantly, in order to achieve high compliance, adherence to diet must be monitored closely by the dietitian (for practical reasons at least monthly during the first couple of months) in cooperation with the paediatrician following a family approach.

Although several studies have documented the safety of exposure to soya-based formula in infancy on endocrinological and reproductive outcome in young adulthood ${ }^{30}$ there is hardly any data on the safety of prolonged soya intake in children. It is thus not surprising that the scientific community has seen a recent discussion on potential dangers of regular soya intake in the long run ${ }^{31}$.

In conclusion, diet is indisputably the cornerstone in the treatment of paediatric patients with elevated serum cholesterol concentrations when aiming at lowering cholesterol levels and thereby postponing the use of cholesterol-lowering agents. Inclusion of soya products may offer an additional long-term dietary option in hypercholesterolaemic paediatric patients.

\section{Acknowledgements}

We gratefully acknowledge the excellent support provided by the staff of the Paediatric Out-patient Department at Vienna Medical University Hospital. We thank C. Franz, A. Fekete and S. Daemon for their expert support with blood sampling and evaluation of the dietary records.

\section{References}

1. American Academy of Pediatrics (1972) Committee on Nutrition: childhood diet and coronary heart disease. Pediatrics 49 , 305-307.

2. Goldstein JL, Schrott HG, Hazzard WR, Bierman EL \& Motulsky AG (1973) Hyperlipidemia in coronary heart disease II. Genetic analysis of lipid levels in 176 families and delineation of a new inherited disorder, combined hyperlipidemia. J Clin Invest 52, 1544-1568.

3. Hoffmann U, Dirisamer A, Heher S, Kostner K, Widhalm K \& Neunteufl T (2002) Relation of peripheral flow-mediated vasodilatation and coronary arterial calcium in young patients with heterozygous familial hypercholesterolemia. Am J Cardiol 90, $70-73$.

4. Anonymous (1992) American Academy of Pediatrics. National Cholesterol Education Program: Report of the Expert Panel on Blood Cholesterol Levels in Children and Adolescents. Pediatrics 89, 525-584.

5. Keys A, Anderson JT \& Grande F (1958) Effect on serum cholesterol in man of mono-ene fatty acid (oleic acid) in the diet. Proc Soc Exp Biol Med 98, 387-391.

6. Grundy SM (1986) Comparison of monounsaturated fatty acids and carbohydrates for lowering plasma cholesterol. $N$ Engl $J$ Med 314, 745-748.

7. Mensink RP \& Katan MB (1987) Effect of monounsaturated fatty acids versus complex carbohydrates on high-density lipoproteins in healthy men and women. Lancet i, 122-125.

8. Zhan S \& Ho SC (2005) Meta-analysis of the effects of soy protein containing isoflavones on the lipid profile. Am J Clin Nutr 81, 397-408.

9. Sacks FM, Lichtenstein A, Van Horn L, Harris W, Kris-Etherton P \& Winston MAmerican Heart Association Nutrition Committee (2006) Soy protein, isoflavones, and cardiovascular health: an American Heart Association Science Advisory for professionals from the Nutrition Committee. Circulation 113, $1034-1044$

10. Glueck CJ, Tsang RC, Fallat RW \& Mellies MJ (1977) Diet in children heterozygous for familial hypercholesterolemia. Am J Dis Child 131, 162-166.

11. Gaddi A, Descovich GC, Noseda G, Fragiacomo C, Nicolini A, Montanari G, Vanetti G, Sirtori M, Gatti E \& Sirtori CR (1987) Hypercholesterolaemia treated by soybean protein diet. Arch Dis Child 62, 274-278.

12. Widhalm K, Brazda G, Schneider B \& Kohl S (1993) Effect of soy protein diet versus standard low fat, low cholesterol diet on lipid and lipoprotein levels in children with familial or polygenic hypercholesterolemia. J Pediatr 123, 30-34.

13. Williams RR, Schumacher MC, Barlow GK, Hunt SC, Ware JL Pratt M \& Latham BD (1993) Documented need for more effective diagnosis and treatment of familial hypercholesterolemia according to data from 502 heterozygotes in Utah. Am J Cardiol 72, 18D-24D.

14. Widhalm K, Maxa E \& Zyman H (1978) Effect of diet and exercise upon the cholesterol and triglyceride content of plasma lipoproteins in overweight children. Eur $J$ Pediatr 127, $121-126$.

15. Laurin D, Jacques H, Moorjani S, Steinke FH, Gagne C, Brun D \& Lupien PJ (1991) Effects of a soy-protein beverage on plasma lipoproteins in children with familial hypercholesterolemia. $\mathrm{Am}$ J Clin Nutr 54, 98-103.

16. Anderson JW, Johnstone BM \& Cook-Newell ME (1995) Metaanalysis of the effects of soy protein intake on serum lipids. $N$ Engl J Med 333, 276-282.

17. Rose V, Allen DM, Pearse RG \& Chapell J (1976) Primary hyperlipoproteinemia in childhood and adolescence: identifi- 
cation and treatment of persons at risk for premature atherosclerosis. Can Med Assoc J 115, 753-756, 779.

18. Teixeira SR, Potter SM, Weigel R, Hannum S, Erdman JW \& Hasler CM (2000) Effects of feeding 4 levels of soy protein for 3 and $6 \mathrm{wk}$ on blood lipids and apolipoproteins in moderately hypercholesterolemic men. Am J Clin Nutr 71, 1077-1084.

19. Rosell MS, Appleby PN, Spencer EA \& Key TJ (2004) Soy intake and blood cholesterol concentrations: a cross-sectional study of 1033 pre- and postmenopausal women in the Oxford arm of the European Prospective Investigation into Cancer and Nutrition. Am J Clin Nutr 80, 1391-1396.

20. Hoie LH, Graubaum HJ, Harde A, Gruenwald J \& Wernecke KD (2005) Lipid-lowering effect of 2 dosages of a soy protein supplement in hypercholesterolemia. Adv Ther 22, 175-186.

21. Lamon-Fava S (2000) Genistein activates apolipoprotein A-I gene expression in the human hepatoma cell line Hep G2. J Nutr 130, 2489-2492.

22. Nilausen K \& Meinertz H (1998) Variable lipemic response to dietary soy protein in healthy, normolipemic men. Am J Clin Nutr 68, 1380S-1384S.

23. Lovati MR, Manzoni C, Canavesi A, Sirtori M, Vaccarino V, Marchi M, Gaddi G \& Sirtori GR (1987) Soybean protein diet increases low density lipoprotein receptor activity in mononuclear cells from hypercholesterolemic patients. J Clin Invest 80, $1498-1502$.

24. Gianazza E, Eberini I, Arnoldi A, Wait R \& Sirtori GR (2003) A proteomic investigation of isolated soy proteins with variable effects in experimental and clinical studies. $J$ Nutr 133, 9-14.

25. Manzoni C, Duranti M, Eberini I, Scharnag H, März W, Castiglioni S \& Lovati MR (2003) Subcellular localization of soybean 7S globulin in HepG2 cells and LDL receptor up-regulation by its $\alpha^{\prime}$ constituent subunit. J Nutr 133, 2149-2155.

26. Huff MW \& Carroll KK (1980) Effects of dietary protein on turnover, oxidation, and absorption of cholesterol, and on steroid excretion in rabbits. J Lipid Res 21, 546-548.

27. West CE, Beynen AC, Terpstra AH, Scholz KE, Carroll KK \& Woodward CJ (1983) The nature of dietary protein and serum cholesterol. Atherosclerosis 46, 253-256.

28. Borradaile NM, de Dreu LE, Wilcox LJ, Edwards JY \& Huff MW (2002) Soya phytoestrogens, genistein and daidzein, decrease apolipoprotein B secretion from HepG2 cells through multiple mechanisms. Biochem J 366, 531-539.

29. Castiglioni S, Manzoni C, D’Uva A, Spiezie R, Monteggia E, Chiesa G, Sirtori CR \& Lovati MR (2003) Soy proteins reduce progression of a focal lesion and lipoprotein oxidizability in rabbits fed a cholesterol-rich diet. Atherosclerosis 171, $163-170$.

30. Strom BL, Schinnar R, Ziegler EE, Barnhart KT, Sammel MD, Macones GA, Stallings VA, Drulis JM, Nelson SE \& Hanson SA (2001) Exposure to soy-based formula in infancy and endocrinological and reproductive outcomes in young adulthood. JAMA 286, 807-814.

31. Siegel-Itzkovich J (2005) Health committee warns of potential dangers of soya. BMJ 331, 254. 